\title{
Morphological Genetic Markers for Selection of Broiler Lines
}

Author(s)

Schmidt GS $S^{1,3}$

Coutinho $\mathrm{LL}^{2,3}$

Figueiredo EAP de ${ }^{1,3}$

Ledur $\mathrm{MC}^{1}$

Alves $\mathrm{HJ}^{3}$

${ }^{1}$ EMBRAPA Suínos e Aves

2 Escola Superior de Agricultura "Luiz de Queiróz" - ESALQ/USP

${ }^{3}$ CNPq Scholarship

\section{Mail Address}

Gilberto Silber Schmidt

Embrapa Suínos e Aves

BR 153 Km 110, Caixa Postal 21

Vila Tamadaré

Concórdia, SC

89.700-000

Fone: $(0 x \times 49) 442-8555$

Fax: (0xx49) 442-8559

E-mail: schmidt@cnpsa.embrapa.br

\section{Keywords}

Genetic, heritability, selection, somite.
Arrived: june/02

Approved: august/03

\section{ABSTRACT}

Two paternal broiler lines (LL and LLC, originated from the same stock in 1998) of Embrapa Suinos e Aves genetic program were used. Line LL had been selected for eight generations for rapid growth while LLc had been mated randomly, without selection, as a control line. In the last generation, 30 males and 240 females were used in hierarchical matings with pedigree control to determine sire effect. The same number of birds were used, but matings were at random for LLC. Eggs of both lines were incubated and embryos were collected in different development stages $(40,45,50,55$ and 60 hours after setting) in order to determine somite number (NOS). The number of evaluated embryos were 1,967 and 498 for LL and LLC, respectively. This study aimed to determine the changes in somite formation during embryonic development that resulted from artificial selection for heavier body weight. In the evaluated generation, the differences for body weight, feed conversion ratio, carcass and breast yields between LL and LLC were $546 \mathrm{~g} ; 0.16$ FC units, 2.20 and 2.19\%, respectively. NOS was greater in the initial $(40 \mathrm{~h})$ and in the final (60 h) stages for LL and in the intermediary stages (45, 50 and 55 h) for LLC, indicating significant differences in the mechanisms of somite formation and development. Considering that both lines had the same genetic origin, such deviation indicates genetic changes due to artificial selection for body weight. The heritability estimates indicated low additive genetic effect for NOS in the different stages. Since the alterations were due to artificial selection for body weight, one could consider the hypothesis of using such genetic marker throughout family selection.

\section{INTRODUCTION}

The use of biotechnology tools in genetic selection process to improve product yield and quality might have a great impact in animal production. Improvement of growth and feed efficiency resulted in significant gains in traits of economical importance, which reduced production costs. As for the consumer, such result might have an impact on the nutritional quality and cost of products.

At the medium term, molecular and morphological markers might be included as tools to be used in the selection of commercial broiler lines. One morphological marker that have attracted a lot of attention is the amount and distribution of somites (NOS) during embryonic development, since somites are precursors of skeletal muscle cells. Besides, some studies reported that quail embryos from lines selected for rapid growth presented a delay on somite formation when compared to the control line (Coutinho et al., 1993; Coutinho et al., 1996).

The first somites are formed with approximately 30 hours of incubation and continues through the neural tube in a cranium-caudal direction, throughout embryo development. Columnar cells arranged radially 
around a small lumen constitute the first somite. The somite ventral-medial region originates the sclerotome, while dorsal-lateral cells give origin to dermomyotome, which reach maturity and form dermotome and myotome (Kaehn et al. 1988). Ordahl \& Le Douarin (1992) demonstrated that the back muscles are originated from somite cells located next to neural tube in chickens, while cells farther away from the neural tube migrate to other regions and are responsible for musculature formation of the breast, limb and others.

The skeletal musculature has as cell unit the muscle fiber. An increase in diameter (hypertrophy) or in number (hyperplasia) of fiber results in increase of muscle mass. Adults show no hyperplasia and the hypertrophy acquired by physical exercises is inefficient in terms of production. One alternative to increase muscle mass might be to increase the number of muscle fibers during the embryonic phase. Previous studies (Coutinho et al., 1993) showed that somite formation, activation of myogenic factors and myosin expression were delayed in quail lines with an increased number of muscle fibers when compared to the control population.

Myogenic factors are included in a group of genes responsible for determination and differentiation of precursor cells into muscle cells. When these genes are expressed in fibroblast cells, they have the capability to transform such cells in muscle cells (Weintraub et al., 1991). As the number of muscle fibers is defined during the embryonic phase, these findings indicated for the possibility of controlling the number of embryonic muscle precursor cells by manipulating the expression of these genes, with the objective of increasing muscular development.

The order of expression of the genes during chicken embryonic development is different from mammals. The first activated gene is qmf1 (MyoD), followed by qmf3 (Myf5) and qmf2 (myogenin) (Pownall \& Emerson, 1992; Coutinho et al., 1993).

Studies in quails selected for rapid growth during 87 generations that had a three-fold higher body weight when compared to the control line at four weeks of age showed that the selected population had an increase of $350 \%$ in pectoralis muscle weight and $300 \%$ in DNA content at ten days of age, but there was no difference in the protein/DNA proportion. Besides, there was an increase of $160 \%$ in the number of muscle fibers of the semimembranosus muscle (Fowler et al. 1980). During the embryonic phase, when muscle formation begins, it was observed a delay on somite formation and on expression of qmf1, qmf3, qmf2 and myosin in the selected line (Coutinho et al., 1992).

The aim of this work was to determine alterations in somite formation during embryonic phase due to selection for body weight in meat-type lines of broiler chickens.

\section{MATERIAL AND METHODS}

The experiment was performed at Embrapa Suínos e Aves, in Concórdia, Santa Catarina State, Brazil. Two paternal broiler lines ( $L L$ and $L L C$ ) of the breeding program of Embrapa Suinos e Aves were used. Both lines were originated from the same stock in 1998. Line LL had been selected for eight generations for rapid growth emphasizing body weight at $42 \mathrm{~d}$. The control line LLC was maintained at randomized mating, without selection, in order to be used as an indicative of genetic changes resulting from artificial selection.

Hierarchical mating between 30 males and 240 females (1:8) was used to produce 2,200 eggs, with pedigree control for $\mathrm{LL}$. The same number of sires and randomized mating were used to produce 600 eggs for LLC. Thus, 1,967 and 498 embryos were evaluated for $L L$ and LLC, respectively. Eggs were colleted daily for 5 days at two-week intervals and kept for 12 hours in storage room. Eggs were incubated at $38^{\circ} \mathrm{C}$ and $64 \%$ of relative humidity.

Each set of eggs was submitted to a different period of incubation aiming to evaluate the number of somite (NOS) at 40, 45, 50, 55 and 60 hours of embryonic development. After the incubation period, eggs were removed from incubator and immersed in $15^{\circ} \mathrm{C}$ water to interrupt the embryonic development.

Embryos were removed through an opening at the top of the egg and fixed in a solution of $4 \%$ paraformaldehyde in PBS (Phosphate Buffered Saline, $\mathrm{pH}$ 7.4), during 16 hours at $4^{\circ} \mathrm{C}$. They were dehydrated for 5 min in each solution of a series of alcohols with increasing concentrations (25, 50 and 70\%). Embryos were stored in $70 \%$ ethanol at $-20^{\circ} \mathrm{C}$. One week after collection, the embryos were thawed and mounted on slides for NOS counting by microscopy.

Statistical analysis to determine heritability were performed by least square method using the LSMLMW \& MIXMDL software (Harvey, 1990). Sire and periods of embryonic development effects were included in this model. Means were analyzed with Proc GLM (SAS, 1990) and compared by Tukey's test at $1 \%$ of probability. 


\section{RESULTS AND DISCUSSION}

Growth and carcass traits for LL and LLc lines at the same generation are shown in Table 1. Differences seen for body weight $(546 \mathrm{~g})$, feed conversion (0.16 unity), carcass yield $(2.20 \%)$ and breast with bone yield $(2.19 \%)$ might be considered as a result of genetic gain due to artificial selection.

Table 1 - Means obtained for growth and carcass traits during the evaluated generation of selected (LL) and control (LLC) lines.

\begin{tabular}{lccc} 
Traits & LL & LLc & Deviation \\
& & & \\
Body weight -42 days (g) & 2,270 & 1,724 & 546 \\
Feed conversion (35-42 days) & 2.35 & 2.53 & 0.16 \\
Carcass yield(\%) & 69.87 & 67.67 & 2.20 \\
Breast with bone yield (\%) & 27.07 & 25.88 & 2.19 \\
Fat percentage (\%) & 0.25 & 0.25 & 0.00 \\
\hline
\end{tabular}

Somite numbers (NOS), according to the development phase and line are shown in Table 2 and Figure 1. NOS increased with embryonic development in both lines, but at different rates. NOS was higher in $\mathrm{LL}$ at initial (40 h) and final (50 h) phases, but it was higher in LLC at middle phases (45, 50 and 55 h), which indicated significant differences in the mechanisms of somite formation and development.

\begin{tabular}{|c|c|c|c|c|}
\hline Hours & LL & LLC & Deviation & $\mathrm{H}^{2}$ \\
\hline 40 & $\begin{array}{l}15.57 a \\
\mathbf{( 4 4 3 )}\end{array}$ & $\begin{array}{l}11.89 \mathrm{~b} \\
\mathbf{( 1 0 8 )}\end{array}$ & 3.68 & $0.091 \pm .037$ \\
\hline 45 & $\begin{array}{c}20.59 \mathrm{~b} \\
(517)\end{array}$ & $\begin{array}{c}21.56 a \\
(98)\end{array}$ & -0.81 & $0.190 \pm 0.050$ \\
\hline 50 & $\begin{array}{c}20.60 b \\
\mathbf{( 4 1 2 )}\end{array}$ & $\begin{array}{c}23.76 a \\
(\mathbf{1 0 0})\end{array}$ & -3.16 & $0.090 \pm 0.039$ \\
\hline 55 & $\begin{array}{c}22.14 b \\
\text { (357) }\end{array}$ & $\begin{array}{l}24.39 a \\
(110)\end{array}$ & -2.25 & $0.089 \pm 0.041$ \\
\hline 60 & $\begin{array}{c}31.00 a \\
(238)\end{array}$ & $\begin{array}{c}28.90 \mathrm{~b} \\
\mathbf{( 8 2 )}\end{array}$ & 2.10 & $0.079 \pm 0.050$ \\
\hline
\end{tabular}

Means within the same stage, followed by different letters are statistically different $(p<0.01)$

The delay in somite formation observed during the initial and final phases seems to be related to the rate of cell division, which would be slower for the control line. During cell division, there should be no somite formation, which seems to last longer in the selected line, resulting in a higher number of cells due to artificial selection and, hence, higher number of muscle fibers.

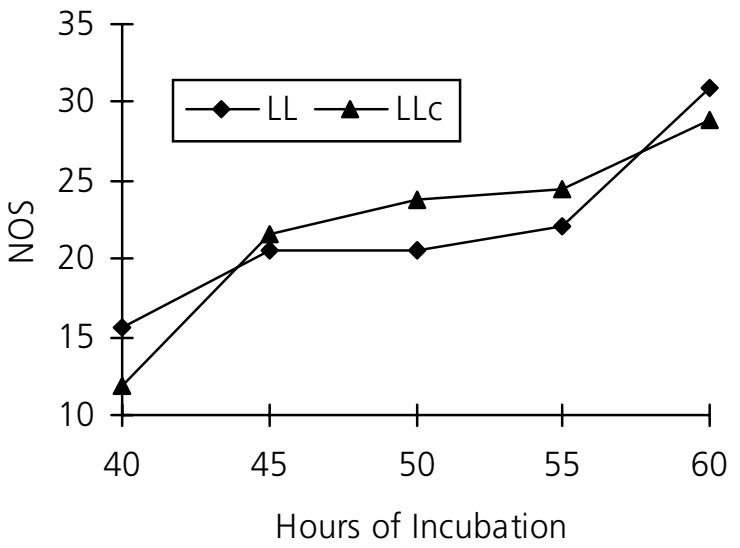

Figure 1. Number of somites (NOS) as function of lines (LLselected and LLc-control) and stage of development (h).

Somite distribution (NOS) during embryonic development originates cells of skeletal musculature and both lines had the same genetic base. Thus, deviations (Figure 2) observed at different periods might be associated with the higher ability of growth by $\mathrm{LL}$, corroborating results obtained by Coleman et al. (1964), Coutinho et al. (1993) and Coutinho et al. (1996). In addition, according to Coutinho et al. (1992), the expression of myogenic factors (qmf1, qmf3, qmf2 and myosin) is delayed in lines selected for rapid growth.

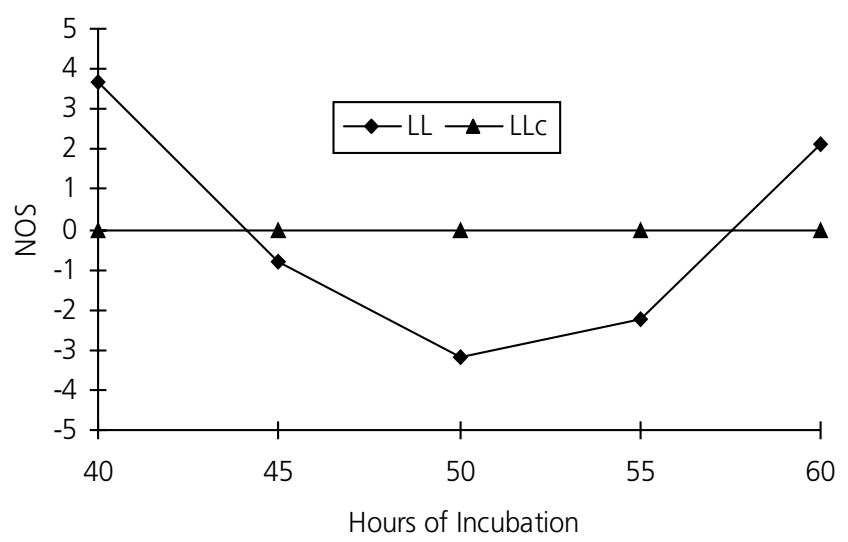

Figure 2. Deviation of number of somites (NOS) between selected (LL) and control (LLC) lines in each stage of development (h).

Quails selected for rapid growth showed an increase of $300 \%$ in body weight, $350 \%$ in pectoralis muscle and $160 \%$ in number of fibers in the semimembranosus muscle (Fowler et al., 1980). Therefore, differences shown between LL and LLC for carcass $(2.20 \%)$ and breast $(2.19 \%)$ yields might be associated to changes 
in somite formation and development as a result of selection for body weight, which is to be accounted for the difference in responses.

\section{CONCLUSION}

The findings of this study raised the hypothesis that the delay in activation of myogenic factors might allow the multiplication of somite cells for an extended period of time. As a result, the number of muscle precursor cells might also increase (hyperplasia). Such increase in the number of precursor cells during embryonic development might result in increased ability of muscle growth during adult life, since the number of muscle fibers is determined close to egg hatching.

Considering that selection for body weight affects somite formation, NOS can be used as an auxiliary tool when selecting birds for meat production. Nevertheless, further studies should be carried out to determine the genetic correlation between NOS and traits of economical importance. Advantages of selection by NOS are not spending resources for broiler breeding until selection age, reduction in the interval between generations, besides the low cost and easy assessment.

\section{REFERENCES}

Coleman JW, Siegel HS, Siegel PB. Delayed somite formation in a quail line exhibiting myofiber hyperplasia is accompanied by delayed expression of myogenic regulatory factors and myosin heavy chain. Poultry Science 1964; 43:53-458.

Coutinho LL, Morris J, Ivarie R. Whole mount in situ detection of low detection of low abundance trancripts of the myogenic factor qmf1 and myosin heavy chain protein quail embryos. Biotechniques $1992 ; 13(5): 722-24$

Coutinho LL, Morris J, Marks HL, Buhr JR, Ivarie R. Delayed somite formation in a quail line exhibiting myofiber hyperplasia is accompanied by delayed expression of myogenic regulatory factors and myosin heavy chain. Development 1993; 17:563-69.

Coutinho LL, Lopes ML, Merzel M, Schmidt GS. Atraso na formação dos somitos em linhagem de frango selecionada para um crescimento rápido. Conferência APINCO de Ciência e Tecnologias Avícolas, p.73. 1996.

Fowler SP, Campion DR, Marks HL, Reagan JO. Analysis of skeletal muscle response to selection for rapid growth in Japan quail (Coturnix japonica). Growth 1980; 44:235-52.

Harvey WR. User's guide for LSMLMW and MIXMDL. Columbus, Ohio State University, p.90, 1990.
Kaehn K, Jacob HJ, Christ B, Hinrichsen K, Poelmann RE. The onset of myotome formation in the chick. Anatomy Embriology 1988; 117:191-01

Ordahl CP, Le Douarin NM. Two myogenic line ages in the developing somite. Development 1992; 14:339-52.

Pownall ME, Emerson CJ. Sequential activation of three myogenic regulatory genes during somite morphogenesis in quail embryos. Developmental Biology 1992; 151(1):67-79.

SAS Statistical Analysis systems User's guide: Stat. Version 6.4, ed. Cary: SAS Institute, v.2, 1990.

Weintraub H, Dwarki VJ, Verna I, Davisi R, Hollenberg S, Snider L, Lassar A, Tapscott SJ. Muscle-specific transcriptional activation by MyoD. Genes Development 1991; 5(8):1377-86. 